FRENCH FILM DIRECTORS
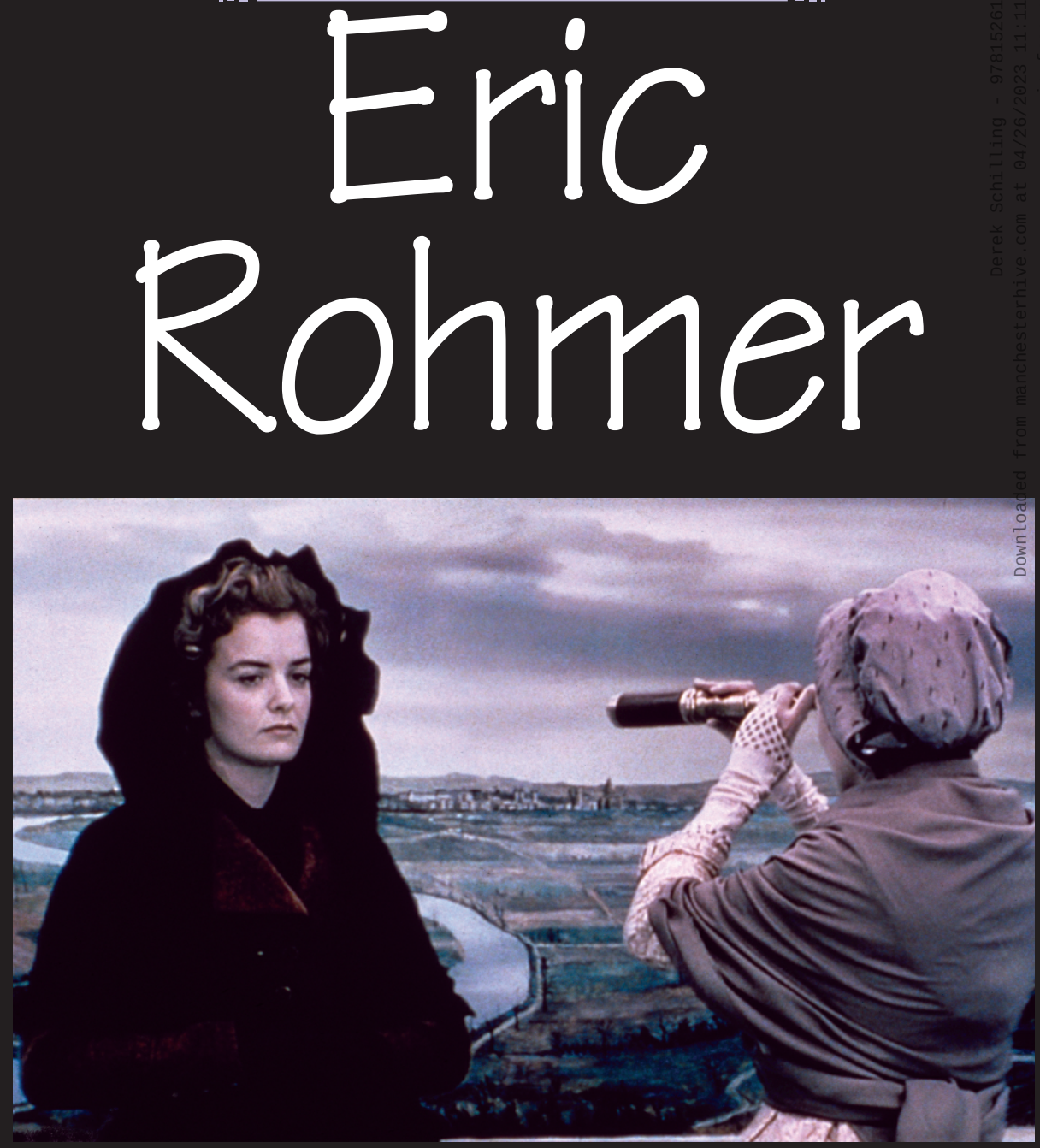

DEREK SCHILLING 


\section{Eric Rohmer}

\section{MANCHESTER 1824}

Manchester University Press 
FRENCH FILM DiRECTORS

DIANA HOLMES and ROBERT INGRAM series editors DUDLEY ANDREW series consultant

Jean-Jacques Beineix PHIL POWRIE

Luc Besson SUSAN HAYWARD

Bertrand Blier SUE HARRIS

Robert Bresson KEITH READER

Leos Carax GARIN DOWD AND FERGUS DALEY

Claude Chabrol GUY AUSTIN

Henri-Georges Clouzot CHRISTOPHER LLOYD

Jean Cocteau JAMES WILLIAMS

Claire Denis MARTINE BEUGNET

Marguerite Duras RENATE GÜNTHER

Georges Franju KATE INCE

Jean-Luc Godard DOUGLAS MORREY

Mathieu Kassovitz WILL HIGBEE

Diane Kurys CARRIE TARR

Patrice Leconte LISA DOWNING

Louis Malle HUGO FREY

Georges Méliès ELIZABETH EZRA

Maurice Pialat MARJA WAREHIME

Jean Renoir MARTIN O'SHAUGHNESSY

Alain Resnais EMMA WILSON

Coline Serreau BRIGITTE ROLLET

André Téchiné BILL MARSHALL

François Truffaut DIANA HOLMES AND ROBERT INGRAM

Agnès Varda ALISON SMITH

Jean Vigo MICHAEL TEMPLE 
FRENCH Film DiRECTORS

\section{Eric Rohmer}

\section{Derek SChILling}

Manchester University Press

MANCHESTER 


\section{Copyright (C) Derek Schilling 2007}

The right of Derek Schilling to be identified as the author of this work has been asserted by him in accordance with the Copyright, Designs and Patents Act 1988.

Published by Manchester University Press

Altrincham Street, Manchester M1 7JA, UK

www.manchesteruniversitypress.co.uk

British Library Cataloguing-in-Publication Data

A catalogue record for this book is available from the British Library

Library of Congress Cataloging-in-Publication Data applied for

ISBN 978 ○ 719072345 hardback

ISBN 978 ○ 719072352 paperback

First published 2007

$\begin{array}{lllllllllll}16 & 1514131211 & 10 & 09 & 08 & 07 & 1098 & 8 & 6543 & 21\end{array}$

Typeset in Scala with Meta display

by Koinonia, Manchester 